\title{
Analisis Framing Pemberitaan Media Online Cnn Indonesia.Com Dan Tirto.Id Mengenai Kasus Pandemi Covid-19
}

\author{
Maulidatus Syahrotin Naqqiyah ${ }^{1}$ \\ ${ }^{1}$ UIN Sunan Ampel Surabaya \\ 1maulinaqqy@gmail.com
}

\begin{abstract}
The state of Indonesia which was intensified by Covid-19 is currently increasingly troubling its citizens. This study discusses the analysis of media texts in the case of the covid-19 pandemic in online media with the aim of finding out how the online media frames news related to the covid-19 pandemic. In this study, the research method use qualitative with framing analysis of pan and Kosicki models as research reference. Research that focuses on two online media that are quite popular in the community including CNN Indonesia.com and tirto.id. The result of the analysis explain that in the online media CNN Indonesia.com the syntatic structure is more emphasis on the role of the goverment so that it can form positive opinions in public. While on tirto.id in its overall structure, it is more pressing on the role of medical personnel so as to open the minds pf the public to remain calm and alert.
\end{abstract}

Keywords: Covid-19, Online Media, Framing Analysis.

\begin{abstract}
Abstrak
Negara Indonesia yang digencarkan oleh covid-19 saat ini semakin meresahkan warganya. Penelitian ini membahas tentang analisis teks media dalam kasus pandemi covid-19 di media online dengan tujuan untuk mengetahui bagaimana media online dalam membingkai berita terkait pandemi covid-19.Didalam penelitian ini, metode penelitian yang digunakan adalah kualitatif dengan analisis framing model Pan dan Kosicki sebagai acuan penelitian. Penelitian yang berfokus pada dua media online yang cukup populer di masyarakat diantaranya adalah CNN Indonesia.com dan tirto.id. Hasil analisis menjelaskan bahwa didalam media online CNN Indonesia.com pada struktur sintaksisnya lebih menekankan pada peran dari pemerintah secara sehingga dapat membentuk opini positif di muka publik. Sedangkan di tirto.id didalam keseluruhan strukturnya lebih menekan pada peran tenaga medis sehingga membuka pikiran khalayak untuk tetap tenang dan waspada.
\end{abstract}

Kata Kunci: Covid-19, Media Online, Analisis Framing

\section{Pendahuluan}

Teknologi media informasi dan komunikasi berkembang pesat seiring dengan canggihnya industri media informasi dan komunikasi, baik itu cetak maupun elektronik yang menawarkan berita dan sensasi. Dengan derasnya arus informasi, manusia mengalami berbagai macam perubahan baik sosiokultural maupun struktural. Kondisi ini memungkinkan betapa pentingnya informasi dalam menanamkan pengetahuan pada peradaban manusia, agar tidak tertinggal dengan kemajuan zaman dan dapat memilah informasi yang baik dan berguna. Untuk mendapatkan informasi dapat melalui bacaan atau mendengar berita, yang salah satunya bisa didapatkan dengan membeli majalah, surat kabar, tabloid dan sebagainya. Bagi sebagian masyarakat dengan membaca lebih memberikan

Jurnal Kopis: Kajian Penelitian dan Pemikiran Komunikasi Penyiaran Islam

Volume 03, Issue 1, Agustus 2020 
keyakinan kepada dirinya karena ada proses intelektual dan intepretasi yang terjadi ketika membaca berita di media ${ }^{1}$.

Saat ini Indonesia telah digemparkan dengan kasus pandemi Covid-19. Sehingga sangat diperlukannya berita-berita yang dapat di konsumsi secara jelas oleh masyarakat. Sebuah virus yang bermula muncul di Wuhan, Provinsi Hubei Cina ini menyebar dengan cepat ke 190 negara lebih. Wabah ini diberi nama coronavirus disease 2019 (COVID-19) yang disebabkan oleh Severe Acute Respiratory Syndrome Coronavirus-2 (SARS-CoV-2). Penyebaran penyakit ini telah memberikan dampak luas secara sosial dan ekonomi. Masih banyak kontroversi seputar penyakit ini, termasuk dalam aspek penegakkan diagnosis, tata laksana, hingga pencegahan(Susilo et al., 2020).

Sebuah analisis framing didalam penelitian ini secara sederhana digambarkan sebagai analisis untuk mengetahui bagaimana realitas (peristiwa, aktor, kelompok, atau apa saja) dibingkai oleh media. Pembingkaian tersebut tentu saja melalui konstuksi. Realitas sosial dimaknai dan dikonstruksi dengan makna tertentu. Peristiwa dipahami dengan bentukan tertentu. Hasilnya pemberitaan media pada sisi tertentu atau wawancara dengan orang-orang tertentu. Semua elemen tersebut tidak hanya bagian dari teknik jurnalistik tetapi menandai bagaimana sebuah peristiwa dimaknai dan di tampilkan².

Komunikasi media pemerintah pada pandemi Covid-19 mendapat penilaian negatif. Setidaknya dua lembaga swadaya masyarakat (LSM) memberikan penilaian negatif, yaitu: Lembaga Penelitian, Pendidikan, dan Penerangan Ekonomi dan Sosial (LP3ES) dan Institute for Development of Economics and Finance (INDEF). Penilaian negatif LP3ES terhadap komunikasi media pemerintah terkait pandemi Covid-19 diberikan karena pemerintah mengeluarkan 37 pernyataan blunder selama pandemi Covid-193. Komunikasi media yang dilakukan pemerintah pada pandemi Covid-19, berdasarkan pengamatan masih belum efektif. Hal itu disebabkan masih banyaknya pernyataan pihak pemerintah yang kerap berlebihan ${ }^{4}$.

Belajar dari praktik komunikasi melalui media yang dilakukan negara lain yang dinilai berhasil, komunikasi media pada pandemi Covid-19 perlu difokuskan pada satu tujuan, yaitu upaya mencegah meluasnya penularan Covid-19. Perlu diingat, gejala Covid-19 sebagaimana diungkap Shereena, yangmirip dengan influenza dan gangguan pernafasan akibat alergi membutuhkan kebijakan tersendiri dalam menyampaikan konten yang akan dikomunikasikan. Konten yang perlu disampaikan kepada masyarakat adalah bagaimana melakukan deteksi dini yang tepat terhadap gejala Covid-195.

Penelitian analisis framing dengan menggunakan model Zhongdang Pan dan Gerald M. Kosicki ini, sebelumnya pernah dilakukan oleh Hepi Fauzi dengan judul "Analisis Framing Model Pan dan Kosicki Berita Kampanye Pemilihan Presiden Indonesia 2019 Pada Media Cetak Harian Duta Masyarakat Rentang Waktu 23 September -30 November 2018*. Penelitian sebelumnnya ini menguak sejauh mana ideologi dan ekonomi politik media berpengaruh terhadap

\footnotetext{
${ }^{1}$ Ishadi, Prospek Bisnis Informasi di Indonesia, 1 ed. (Bandung: Pustaka Pelopor, 1999).

${ }^{2}$ Eriyanto, Analisis Framing: Konstruksi, Ideologi, Dan Politik Media (Yogyakarta: LkiS, 2002).

${ }^{3}$ I Mawardi, "Ini Daftar37 Pernyataan Blunder Pemerintah Soal Corona Versi LP3ES," news.detik.com, 2020, Soahttps://news. detik.com/berita/d-4967416/ini-daftar-37-pernyataanblunder-pemerintah-soalcsoalc or o n a - v e r s i - 1 p 3 e s ? u t m_s o u r c e $=$ f a c e b o o k \& u t m _ campaign=detikcomsocmed\&utm_ medium=btn\&utm_content=new s\&fbclid=IwAR1UFBHP9 $z f C x k$ eUOqFOQokS4CxYzx188zkuRlf ts-oUuajpdYQ9gm8rVD.

${ }^{4}$ Handrini Ardiyanti, "Komunikasi Media Yang Efektif Pada Pandemi Covid-19," INFO Singkat;Kajian Singkat Terbadap Isu Aktual Dan Strategis Vol.12, no. 7 (2020): 26.

5 M.A Shereena dkk., "COVID-19 infection: Origin, transmission, and characteristics of human corona viruses," Journal Of Advanced Research Vol.24 (2020): 91-98.

${ }^{6}$ Hepi Fauzi, “ANALISIS FRAMING MODEL PAN DAN KOSICKI BERITA KAMPANYE PEMILIHAN PRESIDEN DAN WAKIL PRESIDEN INDONESIA 2019 PADA MEDIA CETAK HARIAN DUTA MASYARAKAT RENTANG WAKTU 23 SEPTEMBER - 30 NOVEMBER 2018"' (Surabaya, UIN Sunan Ampel Surabaya, 2019).
}

Jurnal Kopis: Kajian Penelitian dan Pemikiran Komunikasi Penyiaran Islam

Volume 03, Issue 1, Agustus 2020 
objektivbitas dan netralitas dalam pemberitaan di media cetak harian Duta Masyarakat. Sedangkan penelitian saat ini menggunakan dua media online sebagai fokus analisisnya. Diantara dua media tersebut adalah CNN Indonesia.com dengan Tirto.id. penelitian lainnya juga dilakukan oleh Rieka Mustika yang menganalisis kasus pedofilia di akun Facebook dengan menggunakan analisis framing media model Robert N.Entman ${ }^{7}$.

Penelitian ini bertujuan untuk melihat pembingkaian media online dalam pemberitaan kasus pandemi Covid-19 sehingga lebih tepat menggunakan model analisis framing Zhong Dang Pan dan M. Kosicki karena model ini merupakan model yang paling populer dan banyak dipakai serta Pan dan Kosicki menjabarkan sebuah model yang sangat detail dalam melihat sebuah pembingkaian berita.

Zhong Dang Pan Dan Gerald M. Kosicki (1993) dalam tulisan mereka "Framing Analysis an Approach to News Discourse" membagi menjadi 4 dimensi struktural teks berita sebagai perangkat framing yaitu sintaksis, skrip, tematik dan retoris. Model ini berasumsi bahwa setiap berita mempunyai frame yang berfungsi sebagai pusat dari organisasi ide. Frame berhubungan dengan makna. Bagaimana sesorang memaknai suatu peristiwa dapat dilihat dariperangkat tanda yang dimunculkan dalam teks.

Penelitian ini dibuat untuk "membenturkan" bagaimana pembingkaian sekaligus praktik jurnalisme dari kedua media online tersebut. Secara umum, tentu saja kontruksi dan framing pemberitaan antara media online yang baru hadir dengan media online yang sudah didukung versi Internasional akan berbeda. Hal ini mengacu pada bagaimana konten media online start up bisa bertahan dan menggaet sebanyak-banyaknya pelanggan pembaca setia. Begitu pula sebaliknya, media online yang sudah mempunyai branding di masyarakat, tentu akan mengkonstruksi pemberitaan sesuai kadar framing yang diperlukan

\section{Metode}

Penelitian ini merupakan penelitian kualitatif yang berusaha membongkar konstruksi media. Subjek penelitian ini mengambil dua media online yang cukup di kenal oleh masyarakat yaitu CNN Indonesia.com dan tirto.id. Sedangkan objek penelitiannya merupakan beberapa teks berita pada dua media online tersebut yang di posting selama bulan Mei-Juni 2020. Periode ini dijadikan pilihan sebab pada bulan tersebut merupakan bulan dilakukannya penelitian ini sehingga sangat di mungkinkan akan menghasilkan sebuah novelty yang menguntungkan bagi khalayak pembaca.

Teknik pengumpulan data dalam penelitian ini, peneliti mengambil berita yang menyertakan nama reporter, penulis, editor maupun pencantuman redaksinya sehingga diharapkan data lebih valid. Dalam penelitian ini, peneliti mengambil tiga berita per media. Jumlah ini di tentukan peneliti karena dianggap sudah cukup untuk mewakili bagaimana pembingkaian yang dilakukan dua media tersebut.

Adapun untuk memperkuat gagasan peneliti, pengolahan data diambil dari berbagai sumber. Pertama, melalui sumber utama artikel berita guna mengaitkan 3 sampel berita yang dipilih dari masing-masing media. Kedua, pengolahan data juga mengambil data sekunder baik dari sumber buku, majalah, jurnal maupun sumber-sumber bacaan lainnya. Keterbatasan

\footnotetext{
${ }^{7}$ Rieka Mustika, "ANALISIS FRAMING PEMBERITAAN MEDIA ONLINE MENGENAI KASUS PEDOFILIA DI AKUN FACEBOOK," Jurnal Penelitian Komunikasi Vol.20, no. 2 (2017): 36.

${ }^{8}$ Zamhari, “Jurnalisme Bencana Di Era New Media," Kalijaga Journal Of Communication 1, no. 2 (2019): 197.
} 
penelitian ini tidak menyertakan wawancara dalam proses pengambilan sumber data serta pengolahannya

\section{Hasil dan Pembahasan}

CNN Indonesia merupakan salah satu media pemberitaan yang bergelut dibidang media massa penyiaran. CNN Indonesia (Cable News Network) merupakan sebuah stasiun televisi dan situs berita yang dimiliki oleh PT. Transmedia Corpora. CNN Indonesia menyajikan beragam konten siaran diantaranya ialah berita nasional, Internasional. Serta berita bisnis, olahraga, teknologi dan hiburan. CNN Indonesia disiarkan pertama kali pada hari Senin, 17 Agustus 2015. Peluncuran utamanya berlangsung sejak 15 Desember 2015 dalam rangka memperingati ulang tahun Transmedia yang ke $14{ }^{9}$. Kerjasama yang dijalin antara CNN Indonesia dengan CNN Internasional adalah kerjasama kemitraan, yaitu CNN Indonesia membeli license untuk menyiarkan CNN di Indonesia. Meskipun demikian, CNN Indonesia masih tetap dalam pengawasan $\mathrm{CNN}$ Internasional dalam menjaga kualitas berita yang di tayangkan ${ }^{10}$. Dalam hal ini CNN Internasional memiliki pengaruh besar pada CNN Indonesia. Biar bagaimanapun CNN Indonesia harus mampu memenuhi standart yang telah ditetapkan oleh CNN Internasional dalam memproduksi berita. Sehingga demikian, produksi berita ataupun pengemasan berita dari CNN Indonesia yang tidak sesuai dengan standart dari CNN Internasional maka izin siaran yang diberikan dapat dicabut swaktu-waktu ${ }^{11}$.

Sekilas apabila melihat berita-berita yang ditampilkan dalam portal Tirto.id, dapat disimak bagaimana Tirto berusaha menyajikan informasi yang mendalam dengan dukungan ilustrasi data infografis di setiap beritanya. Pada halaman "Tentang Kami” di situs Tirto.id dijelaskan bahwa nama Tirto berarti air, yang memang mengambil filosofi air, yaitu jernih dan dalam. Hal ini merujuk pada filosofi kejernihan dan kedalaman sebagai gambaran prinsip jurnalisme yang mereka usung. Selain itu Tirto juga merujuk pada nama Pahlawan Nasional sekaligus Bapak Pers Nasional Tirto Adhi Soerjo (1880-1918) yang memanfaatkan surat kabar sebagai alat perlawanan terhadap pemerintah kolonial Hindia Belanda1. Hal menarik lainnya yang patut disimak adalah sosok Sapto Anggoro, pendiri Tirto. Sapto Anggoro sebelumnya merupakan wartawan sekaligus wakil pemimpin redaksi Detik.com. Bahkan Sapto merupakan salah satu generasi pertama yang bekerja di Detik.com sejak didirikannya pada tahun 1998. Setelah keluar dari Detik.com, Sapto kemudian mendirikan Tirto.id pada tahun 2016. Menariknya, Tirto.id justru mengusung praktik jurnalisme yang sangat berbeda dengan Detik.com ${ }^{12}$.

Dalam pendekatan ini perangkat framing dibagi menjadi 4 struktur besar ${ }^{13}$.

1. Struktur Sintaksis

Struktur Sintaksis dapat diamati dari bagan berita. Sintaksis berhubungan dengan bagaimana wartawan menyususn peristiwa, (pernyatan, opini, kutipan, pengamatan atas peristiwa) menjadi sebuah berita. Elemen sintaksis memberi petunjuk yang berguna tentang bagaimana wartawan memaknai peristiwa dan hendak kemana berita tersebut akan dibawa. Bentuk sintaksis yang paling populer adalah pramida terbalik yang dimulai dengan judul

\footnotetext{
9 “Sejarah CNN INDONESIA,” t.t., https://id.wikipedia.org/wiki/CNN_Indonesia.

${ }^{10}$ Widya Rahmatia, "HIERARKI PENGARUH MEDIA DALAM PROGRAM LAYAR PEMILU TERPERCAYA DI CNN INDONESIA” (Jakarta, UIN SYARIF HIDAYATULLAH JAKARTA, 2018).

${ }^{11}$ Rahmatia.

12 Suluh Gembyeng Ciptadi dan Ade Armando, "Upaya Agensi Melawan Logika Jangka Pendek Jurnalisme Daring: Studi Kasus Tirto.id," Jurnal Komunikasi Indonesia Vol. VII, no. 1 (2018): 63

${ }^{13}$ Eriyanto, Analisis Framing: Konstruksi, Ideologi, Dan Politik Media.
}

Jurnal Kopis: Kajian Penelitian dan Pemikiran Komunikasi Penyiaran Islam

Volume 03, Issue 1, Agustus 2020 
headline, lead, episode, latar dan penutup. Dalam bentuk ini bagian yang diatas ditampilkan lebih penting dibanding bagian bawahnya.

2. Struktur Skip

Struktur Skrip melihat bagaimana wartawan mengemas suatu peristiwa. Laporan berita sering disusun sebagai suatu cerita. Hal ini disebabkan 2 hal yaitu pertama untuk menunjukan hubungan antara peristiwa satu dengan sebelumnya, kedua untuk penghubung teks yang ditulis dengan lingkungan komunal pembaca. Bentuk umum dari struktur skrip ini adalah $5 \mathrm{~W}+1 \mathrm{H}$, Who, What, When, Where, Why dan How.

3. Struktur Tematik

Struktur Tematik yaitu cara pandang wartawan atas suatu peristiwa kedalam proposisi, kalimat, atau hubungan antar kalimat yang membentuk teks secara keseluruhan. Struktur tematik berhubungan dengan bagaimana fakta ditulis dalam suatu berita.

4. Struktur Retoris

Struktur Retoris berhubungan dengan cara wartawan menekankan arti tertentu yang digambarkan dari pilihan gaya atau kata. Wartawan mengunakan perangkat retoris ntuk membuat citra, meningkatkan penonjolan pada sisi tertentudan meningkatkan gambaran yang diinginkan dari suatu berita. Terdapat beberapa elemen dalam struktur retoris diantaranya leksikon, pemilihan dan pemakaian kata untuk menandai atau mengambarkan peristiwa. Selain melalui kata penekanan dapat dilakukan melalui grafis berupa gambar, tabel, foto dll.

Analisis pembingkaian ini dilakukan terhadap beberapa berita yang ada di CNN Indonesia.com dan tirto.di terkait kasus pandemi Covid-19. Dengan menggunakan analisis mode Pan dan Kosicki, penelitian ini berusaha menelaah bagaimana pembingkaian kasus Pandemi Covid-19 oleh kedua media online tersebut.

\section{CNN Indonesia.com}

\section{Analisis Berita 1}

\section{Judul : Tes Corona di DKI Tinggi, Pemerintah Bandingkan dengan Korsel} Sumber : CNN Indonesia.com

Ringkasan : Jubir Pemerintah untuk penanganan Covid-19 Ahmad Yurianto dalam konferensi pers harian mengatakan bahwa pengujian spesimen yang dilakukan di DKI Jakarta tak kalah dengan beberapa negara tetangga termasuk Korea Selatan.

\section{Analisis :}

1. Struktur Sintaksis. Analisis secara sintaksis dapat diketahui bahwa media didalam berita ini menunjukkan kepada masyarakat bahwa aksi pemerintah DKI Jakarta dalam kasus covid-19 ini telah sesuai dengan instruksi untuk menggencarkan pemeriksaan secara masif dari Presiden Joko Widodo.

2. Struktur Skip. Sebagai konsumsi khalayak, didalam berita ini secara analisis Skip telah lengkap sesuai dengan $5 \mathrm{~W}+1 \mathrm{H}$. Sehingga sangat layak untuk dikonsumsi oleh berbagai kalangan masyarakat.

3. Struktur Tematik. Berita ini ditulis berdasarkan pernyataan langsung oleh Jubir Presiden yaitu Achmad Yurianto yang kemudian dikuatkan oleh wartawan dengan menambahkan pernyataan Wakil Gubernur DKI Jakarta Ahmad Riza Patria.

4. Struktur Retoris. Isi dalam berita ini semua membahas mengenai upaya aksi pemerintah DKI Jakarta yang sampai sejauh ini telah mencapai diatas standart WHO. 
Kata melebihi standart WHO yang berarti upaya pemerintah DKI Jakarta yang maksimal, akan secara langsung terngiang dalam benak khalayak.

\section{Analisis Berita 2}

\section{Judul : BMKG Ungkap Pengaruh Suhu dan Penyebaran Covid-19 di RI \\ Sumber : CNN Indonesia.com}

Ringkasan : Tidak ada bukti yang cukup kuat untuk menyatakan bahwa suhu dan kelembaban menjadi salah satu faktor penyebaran covid-19. Supari, Kepala Sub Bidang Peringatan Dini Iklim BMKG menyatakan bahwa suhu dan kelembaban dengan penyebaran covid-19 merupakan sebuah kebetulan saja.

\section{Analisis :}

1. Struktur Sintaksis. Judul yang digunakan didalam berita ini yaitu "BMKG Ungkap Pengaruh Suhu dan Penyebaran Covid-19" menjadi pemicu ketertarikan khalayak akan kelanjutan berita karena menjawab rasa penasaran pengikut informasi kasus covid-19.

2. Struktur Skip. Secara rumus $5 \mathrm{~W}+1 \mathrm{H}$ konten didalam berita telah disertakan secara epik, sehingga memungkinkan untuk layak di konsumsi oleh khalayak.

3. Struktur Tematik. Dengan memperhatikan kalimat yang dipakai dalam konten berita ini, yang mengutamakan peran BMKG yang mengadakan penelitian terkait suhu dan kelembaban.

“.......mengatakan hasil penelitian gabungan BMKG menunjukkan bahwa suhu berkorelasi positif secara signifikan dengan kasus harian covid-19. Sedangkan kelembaban berkorelasi negatif'

4. Struktur Retoris. Berita ini ditulis berdasarkan dari pernyataan perwakilan BMKG yang kemudian mengkaitkan dengan hasil penelitian dari ilmuan Cina sebagai negara yang terpapar covid-19 pertama kalinya.

“....dalam penelitian yang dilakukan oleh Liu J (2020) menunjukkan bahwa kasus covid-19 semakin meningkat ketika suhu di China meningkat.”

“.....dalam penelitian lainnya yang dilakukan oleh Yao Y (2020) menunjukkan bahwa semakin tinggi suhu di Hubei maka kasus menurun. Sedangkan di luar Hubei, dia menyebut kasus meningkat saat suhu juga meningkat."

\section{Analisis Berita 3}

\section{Judul \\ : Obat Dexamethasone Berpotensi Tekan Risiko Kematian Covid-19}

Sumber

: CNN Indonesia.com

Ringkasan : Ditemukannya obat yang telah tersedia di pasaran masyarakat secara luas yaitu obat steroid Dexamethasone sebagai salah satu kunci untuk menekan angka kematian akibat covid-19.

\section{Analisis :}

1. Struktur Sintaksis. Jika melihat dari segi judul dan leadnya, berita ini menunjukkan bahwasannya sebuah obat yang tersedia secara luas tersebar di masyarakat memiliki potensi menjadi salah satu kunci untuk menekan angka kematian akibat covid-19.

2. Struktur Skip. Didalam berita ini, unsur yang paling di tonjolkan adalah unsur who yang menjadi uji coba dalam penelitian untuk menemukan potensi terkait obat tersebut.

Jurnal Kopis: Kajian Penelitian dan Pemikiran Komunikasi Penyiaran Islam 
“.....penelitian dilakukan terhadap 2.100 pasien Covid-19 yang dirawat di sejumlah rumah sakit di Inggris secara acak. Peneliti fokus pada risiko kematian yang disebabkan oleh covid-19."

3. Struktur Tematik. Berita ini mengusung pernyataan Direktur jenderal WHO untuk lebih meyakinkan hasil temuan kepada khalayak

4. Struktur Retoris. Dari segi retoris, berita ini menunjukkan adanya apresiasi dari WHO terkait hasil terobosan ilmiah penggunaan obat steroid tersebut. Akan tetapi sebenarnya ini terobosan tersebut masih merupakan hasil studi pendahuluan dan belum ada proses penelaahan lebih lanjut.

tirto.id

Analisis Berita 4

Judul : 4 Penjemput Paksa Jenazah COVID-19 di Surabaya Jadi Tersangka

Sumber : tirto.id

Ringkasan : 4 orang penjemput paksa jenazah terkonfirmasi covid-19 di RS.Paru Surabaya menjadi tersangka. Selain menjemput jenazah secara paksa, tersangka juga tidak menguburkan jenazah sesuai dengan protokol kesehatan.

Analisis :

1. Struktur Sintaksis. Judul yang di gunakan "4 Penjemput Paksa Jenazah COVID-19 di Surabaya Jadi Tersangka" menjadi pemicu ketertarikan kelanjutan berita bagi khalayak yang selalu update perkembangan berita covid-19 ini.

2. Struktur Skip. Dalam struktur Skip ini, lebih di tekankan pada why dengan kronologi yang diceritakan sebagaimana pemaparan oleh Humas Polda Jatim serta Dirut RS.Paru Surabaya.

“....keempat orang tersangka ini terancam pasal berlapis,"pasalnya jelas yaitu adanya UU Wabah Penyakit, UU Karantina Wilayah dan KUHP pada Pasal 214 dan pasal 216 ancaman hukuman diatas lima tahun," katanya (Humas Polda Jatim)

3. Struktur Tematik. Dengan meninjau kalimat yang di pakai dalam konten berita ini lebih mengutamakan peran dokter di RS.Paru surabaya.

"....tidak ada polisi waktu itu. Petugas sampai berlindung ke depot air isi ulang"

4. Struktur Retoris. Kata berlindung yang dipilih menunjukkan kedramatisan dibandingkan kata bersembunyi sehingga khalayak lebih tertarik pada isi berita dan menimbulkan rasa iba pada petugas yang mungkin ketakutan.

\section{Analisis Berita ke 5}

Judul

: Antibodi SARS Dilaporkan Dapat Memblokir Infeksi Virus COVID-

19

Sumber : tirto.id

Ringkasan : terdapat penelitian terbaru bahwasannya sampel darah dari pasien SARS pada tahun 2003 mengandung antibodi yang dapat memblokir virus baru di belakang pandemi covid-19.

Jurnal Kopis: Kajian Penelitian dan Pemikiran Komunikasi Penyiaran Islam Volume 03, Issue 1, Agustus 2020 
Analisis

1. Struktur Sintaksis. Berita ini mengusung judul yaitu "Antibodi SARS Dilaporkan Dapat Memblokir Infeksi Virus COVID-19" dengan artian bahwa media ingin menampilkan bahwa para ilmuwan dan peneliti semua bekerja keras yang pada akhirnya menemukan sebuah antibody yang dapat memblokir virus SARS-CoV-2 di belakang pandemi.

".....dan saat ini, sebuah penelitian terbaru dari sebuah perusahaan biotek menyatakan bahwa sampel darah dari seorang pasien yang menderita SARS terkait virus sekitar 17 tahun yang lalu mengandung antibodi yang kemungkinan dapat memblokir virus SARS-CoV-2 di belakang pandemi Covid-19"

2. Struktur Skip. Analisis pada struktur skip disini lebih menekankan pada who, siapa yang melakukan penelitian. Karena banyak dikutip dari berbagai hasil penelitian yang berbeda-beda antara di 17 tahun yang lalu dengan yang saat ini.

3. Struktur Tematik. Dalam struktur ini, pada setiap paragrafnya lebih ke dalam menceritakan mengenai hasil-hasil dari beberapa penelitian yang berbeda. Sehingga lebih menguatkan korelasi pada judul berita.

4. Struktur Retoris. Pada struktur retoris, kata “ membuka jalan” pada penutup berita memiliki arti pemberian kesan dan tafsiran secara teoritis terhadap sesuatu serta dapat disimpulkan sebagai sebuah pendapat dan terobosan baru bagi para tenaga medis

".....temuan penelitian telah "membuka jalan" untuk menggunakan antibodi S309, yang akan dikembangkan sebagai vaksin sendiri atau sebagai bagian dari "koktail antibodi" untuk mencegah covid-19"

\section{Analisis Berita 6}

\section{Judul : Apa Itu Dexamethasone yang Diklaim Bisa Sembuhkan Pasien \\ Covid-19?}

\section{Sumber : tirto.id}

Ringkasan : sebuah uji coba baru yang dilakukan oleh Universitas Oxford Inggris menemukan sebuah potensi positif di dalam obat sederhana Dexamethasone.

\section{Analisis :}

1. Struktur Sintaksis. Berdasarkan Judul dan lead pada berita tersebut menunjukkan bahwa media lebih ke arah untuk memberikan pengertian seputar obat sederhana yang selama ini sudah tersebar luas di kalangan masyarakat.

2. Struktur Skip. Menganalisis dari struktur skipnya, berita ini menekankan pada rumus What yang menjelaskan secara detile seputar Dexamethasone.

“....dexamethasone dikategorikan sebagai steroid yang dapat diresepkan dalam bentuk tablet atau sebagai larutan oral, tetes mata, serta tetes teling".

3. Struktur Tematik. Melihat dari segi tematiknya, kalimat yang digunakan menunjukkan bahwa berita ini banyak di sertakan opini-opini dari beberapa tenaga medis dan media-media terpercaya.

“....Mayo Clinic mewartakan..." “.....seperti di lansir dari New York...” dan “.....lapor BBC News"

4. Struktur Retoris. Isi berita ini memuat hasil-hasil penelitian tenaga medis terkait covid-19 dalam menemukan obat penyembuh untuk pasien yang terserang virus mematikan tersebut.

Jurnal Kopis: Kajian Penelitian dan Pemikiran Komunikasi Penyiaran Islam

Volume 03, Issue 1, Agustus 2020 
“.....sebanyak 2.104 pasien diacak untuk menerima dexsamethasone $6 \mathrm{mg}$ sekali sehari selama sepuluh hari dan di bandingkan dengan 4.321 pasien yang diacak untuk perawatan biasa saja."

\section{Kesimpulan}

Analisis yang dilakukan pada kedua media ini mendapatkan kesimpulan bahwa media yang di analisis yaitu CNN Indonesia.com dan tirto.id. Dalam CNN Indonesia, secara struktur sintaksisnya media lebih menekankan pada maksimalisasi peran pemerintah sehingga dapat membentuk opini positif dalam benak khalayak. Sedangkan didalam tirto.id, peran yang di tekankan lebih ke dalam tenaga medis dalam menangani covid-19 sehingga dapat membentuk opini positif pada khalayak. Penelitian

Hasil penelitian ini perlu untuk dikembangkan lebih mendalam, sehingga mampu untuk menambah khazanah keilmuan bagi khalayak khususnya terkait pembingkaian media dalam kasus covid-19 yang sedang melanda beberapa negara di dunia khususnya Indonesia.

\section{Sitasi dan Daftar Pustaka}

Ardiyanti, Handrini. "Komunikasi Media Yang Efektif Pada Pandemi Covid-19." INFO Singkat;Kajian Singkat Terhadap Isu Aktual Dan Strategis Vol.12, no. 7 (2020): 26.

Ciptadi, Suluh Gembyeng, dan Ade Armando. "Upaya Agensi Melawan Logika Jangka Pendek Jurnalisme Daring: Studi Kasus Tirto.id.” Jurnal Komunikasi Indonesia Vol. VII, no. 1 (2018): 63.

Eriyanto. Analisis Framing: Konstruksi, Ideologi, Dan Politik Media. Yogyakarta: LkiS, 2002.

Fauzi, Hepi. “ANALISIS FRAMING MODEL PAN DAN KOSICKI BERITA KAMPANYE PEMILIHAN PRESIDEN DAN WAKIL PRESIDEN INDONESIA 2019 PADA MEDIA CETAK HARIAN DUTA MASYARAKAT RENTANG WAKTU 23 SEPTEMBER - 30 NOVEMBER 2018." UIN Sunan Ampel Surabaya, 2019.

Ishadi. Prospek Bisnis Informasi di Indonesia. 1 ed. Bandung: Pustaka Pelopor, 1999.

Mawardi, I. "Ini Daftar37 Pernyataan Blunder Pemerintah Soal Corona Versi LP3ES." news.detik.com, 2020. Soahttps://news. detik.com/berita/d-4967416/ ini-daftar-37pernyataanblunder- pemerintah-soalcsoalc or o n a - versi-1 p 3 e s ? u t m _ s o u r c e $=\begin{array}{lllllllllllllllll}\mathrm{f} & \mathrm{a} & \mathrm{c} & \mathrm{e} & \mathrm{b} & \mathrm{o} & \mathrm{o} & \mathrm{k} & \& & \mathrm{u} & \mathrm{t} & \mathrm{m} & \text { _ campaign=detikcomsocmed\&utm }\end{array}$ medium $=$ btn\&utm_content=new $\quad$ s\&fbclid=IwAR1UFBHP9zfCxk eUOqFOQokS4CxYzx188zkuRlf ts-oUuajpdYQ9gm8rVD.

Mustika, Rieka. "ANALISIS FRAMING PEMBERITAAN MEDIA ONLINE MENGENAI KASUS PEDOFILIA DI AKUN FACEBOOK.” Jurnal Penelitian Komunikasi Vol.20, no. 2 (2017): 36. 
Rahmatia, Widya. "HIERARKI PENGARUH MEDIA DALAM PROGRAM LAYAR PEMILU TERPERCAYA DI CNN INDONESIA.” UIN SYARIF HIDAYATULLAH JAKARTA, 2018.

Sejarah CNN INDONESIA,” t.t. https://id.wikipedia.org/wiki/CNN_Indonesia.

Shereena, M.A, S Khana, A Kazmic, dan et.al. "COVID-19 infection: Origin, transmission, and characteristics of human corona viruses." Journal Of Advanced Research Vol.24 (2020): 91-98.

Susilo, Adityo, dan dkk. "Coronavirus Disease 2019: Review of Current Literatures." Jurnal Penyakit Dalam Vol. 7, no. 1 (2020): 47.

Zamhari. "Jurnalisme Bencana Di Era New Media.” Kalijaga Journal Of Communication 1, no. 2 (2019): 197.

Jurnal Kopis: Kajian Penelitian dan Pemikiran Komunikasi Penyiaran Islam Volume 03, Issue 1, Agustus 2020 